Magdalena GodowsKa

Jagiellonian University

\title{
Academic entrepreneurship as a factor of knowledge spillovers in the regions - the case of Małopolska region
}

With the transition towards a knowledge-based economy, entrepreneurship has become a focus of public policy, especially on the regional level, as one of the most significant factors of economic growth. The knowledge spillover theory of entrepreneurship is based on the assumption that entrepreneurs act as a missing link in the knowledge-based economy by converting incompletely commercialized knowledge into economically significant one. They do so by founding new ventures - start-ups - in order to exploit knowledge created in larger companies, which are unwilling to commercialize new ideas due to a high level of uncertainty. In this sense, starting up a new company acts as a conduit for the spillover of knowledge.

The aim of this paper is to explain the foundations of the knowledge spillover theory of entrepreneurship. This theoretical concept has been developed by David B. Audretsch and Max Keilbach from the Max-Planck Institute of Economics in Jena, Germany. The novelty of their theory is that it inverts the traditional approach to entrepreneurship by pointing at the changing exogenous context as lying at the basis of entrepreneurial activity, rather than the individual characteristics of an entrepreneur.

In the second part of the paper, the analysis of the Małopolska region in the light of the knowledge spillover theory of entrepreneurship is carried out. The special focus is on academic entrepreneurship in the region since the theoretical concept of the knowledge spillover theory of entrepreneurship may well serve as a framework to analyze knowledge-based ventures.

\section{The Knowledge Spillover Theory of Entrepreneurship}

The knowledge spillover theory of entrepreneurship has been developed by inter alia David B. Audretsch and Max Keilbach from the Max-Planck Institute of Economics. Their aim was to introduce an alternative theoretical approach to entrepreneurship by reversing the classical perspective already well developed in management studies. Entrepreneurship 
research is focused on the traditional approach, in which scholars aim at discovering individual traits characteristic of entrepreneurs. The question asked in the literature is about why some individuals decide to set up a new firm while others do not. Typically, the answer is based on pointing at some individual characteristics such as independence, inclination to risk, or creativity, which enable some actors to successfully perceive and seize entrepreneurial opportunities. The existence of entrepreneurial opportunity is taken for granted and fixed. In classical theoretical approaches, there is, therefore, a significant gap concerning the nature and sources of entrepreneurial opportunity (Audretsch and Keilbach 2007: 1242-1243).

On the contrary, in the knowledge spillover theory of entrepreneurship, the focus is on the context of entrepreneurial activity rather than on the cognitive process leading to starting up a new venture. Audretsch and Keilbach pay special attention to a specific context of entrepreneurial activity, i.e. the context rich in knowledge. They build their assumptions on prior works by Alvarez and Barney (2005) and Arrow (1962). The former proved entrepreneurs' willingness to invest under the condition of uncertainty (i.e. when it is impossible to foresee possible outcomes of a market decision and their probability at the moment of taking the decision) due to overreliance on their decision-making abilities and a propensity to generalize on the basis of small samples (Alvarez and Barney 2005: 779). On the other hand, Arrow pointed out that knowledge-based economic activity is more uncertain since it is much more difficult to predict the demand and market outcome of the application of new ideas compared to traditional factors of production (Arrow 1962: 609-618). By linking those concepts, Audretsch and Keilbach state that "contexts rich in knowledge will inherently be characterized by a greater degree of uncertainty, leading to greater entrepreneurial opportunities" (Audretsch and Keilbach 2007: 1244).

According to the knowledge spillover theory of entrepreneurship, investments in new knowledge and ideas are significant sources of entrepreneurship. If, due to highly uncertain outcomes of those new concepts, the incumbent organization (such as a university or research laboratory of a large company) is unwilling to commercialize new knowledge, there is a high likelihood that a new firm (start-up) will be established. Incomplete commercialization of knowledge created in an incumbent organization leads to starting a new firm which serves as knowledge spillover and commercialization channel (Audretsch and Lehmann 2005: 1193). Starting up a firm enables an economic agent to exploit the knowledge created by means of research expenditure of universities and corporations (Audretsch and Keilbach 2007: 1248). On that basis, the authors claim that contexts rich in knowledge, with high levels of investment in research and development, generate a higher level of entrepreneurship, compared to contexts impoverished in knowledge.

In that sense, entrepreneurs serve as a conduit for spillover of knowledge that would otherwise remain uncommercialized, converting scientific knowledge into economically relevant one (Braunerhjelm et al. 2010: 108). Knowledge-based entrepreneurship acts as a missing link between research activity and economic practice. 
ACADEMIC ENTREPRENEURSHIP IN THE LIGHT OF THE KNOWLEDGE SPILLOVER THEORY OF ENTREPRENEURSHIP

As it is pointed out by its authors, the evidence of the knowledge spillover theory of entrepreneurship is limited to new ventures based on knowledge. Knowledge spillovers from incumbent firms are not expected to be observed in low-technology entrepreneurship (Audretsch and Keilbach 2007: 1251). That is why this theoretical concept may well serve as a framework to analyze academic entrepreneurship.

In the knowledge creation system, one can distinguish academic research on the one hand, and industrial research and development (R\&D) on the other hand, which is seen as having potential economic value. Academic research is mostly basic research (theory-oriented). Thus, it does not have immediate economic value. However, the output of academic research can be economically significant in two cases: firstly, when it concerns human capital, i.e. knowledge of university graduates who enter the labour market and enrich it with their competences and skills; secondly, if research output is commercialized by patent approval, licensing or start-up of a new venture (Carlsson et al. 2009: 1197). Therefore, academic start-ups play a key role in knowledge transfer, diffusion and utilization, especially due to unwillingness of the incumbent organization to commercialize research output (Koschatzky and Hemer 2009: 192).

Academic entrepreneurship can be defined as "an activity of a university scientist, $\mathrm{PhD}$ student or a post-doc researcher, who sets up a business company in order to commercialize the results if his or her research" (Franzoni and Lissoni 2009: 164). These knowledge-intensive ventures act as crucial channels of knowledge transfer by building business concepts on the basis of knowledge acquired during academic education and former employment at the university. In that sense, academic entrepreneurship serves as a conduit for the spillover of knowledge since the founders of such ventures are determined to further their research and commercialize its outcomes in which their incumbent institutes have little interest (Koschatzky and Hemer 2009: 213).

The notion of academic entrepreneurship consists of two types of ventures: spin-offs (which are funded by university scientists and are financially, legally or institutionally associated with the incumbent organization) and spin-outs (start-ups which are independent of the parent institution). In both cases, there exist numerous internal impediments to converting academic research into economically relevant knowledge. Those barriers are mostly organizational, such as university rules on intellectual property, lack of incentives to commercialize research output, as well as behavioural barriers, such as faculty's dislike for commercialization and entrepreneurial attitudes of scientists. The higher the barriers, the more important share of research transfer is carried out by skilled labour and human capital, compared to commercialization of knowledge (Carlsson et al. 2009: 1196).

Apart from internal factors influencing the emergence of academic firms, regional environment plays a crucial role in promoting and facilitating development of academic entrepreneurship. Among regional factors one can point out: the system of incubator organizations and institutions promoting entrepreneurship (technological parks, clusters, centres of technological transfer), the quality of government and self-government measures of entrepreneurship support, the efficiency of financing institutions, as well as 
entrepreneurial-friendly climate, determining positive attitudes of bureaucracy and society towards entrepreneurs (Koschatzky and Hemer 2009: 194).

\section{MAŁOPOLSKA REGION - THE POTENTIAL OF RESEARCH AND DEVELOPMENT SECTOR}

According to Audretsch and Keilbach, knowledge spillover entrepreneurship demonstrates a high propensity to locate in geographical proximity of knowledge sources, e.g. universities or research institutes (Audretsch and Keilbach 2005: 22). The Małopolska region, or more precisely Kraków, can be defined as a context rich in knowledge due to a significant potential of the research and development sector.

There are thirty three universities and colleges in the region $(7.2 \%$ of Polish universities), among which state schools of higher education are a majority. Two-thirds of universities in Małopolska are located in the capital of the region. Two universities are highly ranked in the ranking of best universities in Poland (the Jagiellonian University on the first place and AGH University of Science and Technology on the sixth place; source: Ranking Uczelni Akadmickich 2012, http://www.perspektywy.pl/index.php?option=com content\&task=view\&id=5074\&Itemid=909).

Tab. 1. Types of universities in Małopolska voivodship in 2009

\begin{tabular}{|l|c|c|}
\hline \multicolumn{1}{|c|}{ Type of university } & Poland & $\begin{array}{c}\text { Małopolska } \\
\text { voivodship }\end{array}$ \\
\hline universities and colleges & 454 & 33 \\
\hline universities & 19 & 1 \\
\hline technical universities & 23 & 2 \\
\hline agricultural universities & 7 & 1 \\
\hline economic universities & 80 & 7 \\
\hline pedagogical universities & 18 & 2 \\
\hline medical universities & 9 & 0 \\
\hline maritime universities & 2 & 0 \\
\hline physical education universities & 6 & 3 \\
\hline artistic universities & 21 & 1 \\
\hline theological universities & 15 & 15 \\
\hline other (including state schools of higher education) & 254 & 25 \\
\hline
\end{tabular}

Source: Local Data Bank, Central Statistical Office

The majority of students in the region are enrolled in economic studies and the humanities ( $55 \%$ of students), while only one third is studying engineering and technical majors. 
Tab. 2. Structure of students in Małopolska according to the type of the major (in 2010)

\begin{tabular}{|l|c|}
\hline \multicolumn{1}{|c|}{ Major } & $\begin{array}{c}\text { \% of the overall number } \\
\text { of students }\end{array}$ \\
\hline economics and administration & 22 \\
\hline social studies & 12 \\
\hline engineering & 9 \\
\hline humanities & 8 \\
\hline pedagogy & 8 \\
\hline medicine & 5 \\
\hline production and processing & 5 \\
\hline architecture and construction & 5 \\
\hline public services & 4 \\
\hline informatics & 4 \\
\hline law & 3 \\
\hline biology & 3 \\
\hline environmental protection & 2 \\
\hline agricultural & 2 \\
\hline physics & 2 \\
\hline arts & 2 \\
\hline journalism & 1 \\
\hline mathematics and statistics & 1 \\
\hline security & \\
\hline transport & \\
\hline
\end{tabular}

Source: Local Data Bank, Central Statistical Office

In 2010, the number of didactic staff in the region reached $12656(12.5 \%$ of the overall number in Poland). There were $5342 \mathrm{PhD}$ students in the region in 2010 (14.5\% of the overall number in Poland), among which only $18 \%$ were enrolled in $\mathrm{PhD}$ programmes in technical universities (Local Data Bank, Central Statistical Office).

In 2007, Małopolska was the second Polish region (after the Mazowieckie voivodship) when it comes to the expenditure on research and development (R\&D) per inhabitant. Similarly, Małopolska is one of the two regions where R\&D expenditure in relation to GNP is higher than in Poland in general. What is striking is the high share of R\&D expenditure in the higher education sector in the total R\&D expenditure in Małopolska (over 50\% of overall R\&D expenditure in the region). Also, the higher education sector employs the majority of R\&D staff in the region (over $73 \%$ of the overall number). This confirms the great importance of Małopolska universities in supporting research and innovation processes in the region. 
Tab. 3. Number of graduates in different majors in 2009 in Małopolska

\begin{tabular}{|c|c|}
\hline Major & $\begin{array}{c}\text { Number of } \\
\text { graduates } \\
\text { in } 2009\end{array}$ \\
\hline in general & 41683 \\
\hline economics and administration & 11902 \\
\hline social studies & 5701 \\
\hline pedagogy & 4463 \\
\hline humanities & 3336 \\
\hline engineering & 2457 \\
\hline medicine & 2130 \\
\hline production and processing & 1738 \\
\hline public services & 1453 \\
\hline computer science & 1354 \\
\hline architecture and construction & 1200 \\
\hline agricultural & 934 \\
\hline biology & 917 \\
\hline physics & 790 \\
\hline law & 763 \\
\hline environmental protection & 718 \\
\hline arts & 549 \\
\hline mathematics and statistics & 518 \\
\hline journalism & 380 \\
\hline transport & 257 \\
\hline social welfare & 33 \\
\hline
\end{tabular}

Source: Local Data Bank, Central Statistical Office 


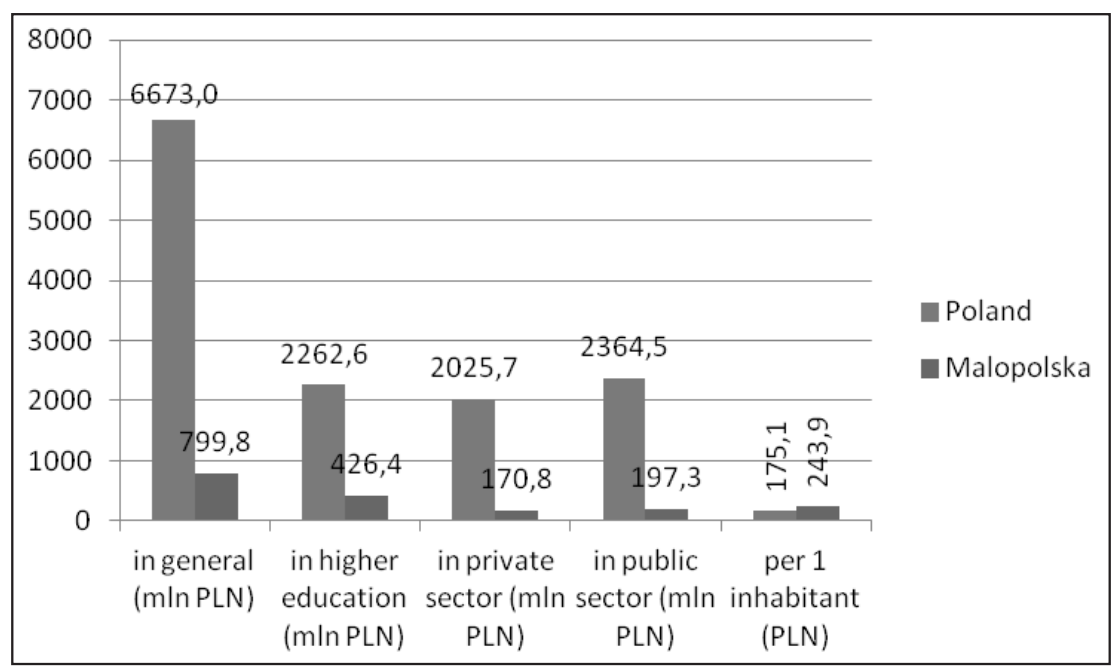

Chart 1. R\&D expenditure in Poland and Małopolska voivodship in 2007

Source: Local Data Bank, Central Statistical Office

Tab. 4. R\&D expenditure in relation to GNP in 2007

\begin{tabular}{|l|l|}
\hline \multicolumn{1}{|c|}{ Poland/voivodship } & in relation to GNP \\
\hline Poland & 0,57 \\
\hline mazowieckie & 1,07 \\
\hline małopolskie & 0,92 \\
\hline lubelskie & 0,54 \\
\hline wielkopolskie & 0,52 \\
\hline łódzkie & 0,51 \\
\hline pomorskie & 0,51 \\
\hline dolnośląskie & 0,41 \\
\hline śląskie & 0,38 \\
\hline podkarpackie & 0,36 \\
\hline warmińsko-mazurskie & 0,29 \\
\hline zachodniopomorskie & 0,24 \\
\hline podlaskie & 0,20 \\
\hline kujawsko-pomorskie & 0,20 \\
\hline opolskie & 0,14 \\
\hline świętokrzyskie & 0,12 \\
\hline lubuskie & 0,09 \\
\hline
\end{tabular}

Source: Local Data Bank, Central Statistical Office 


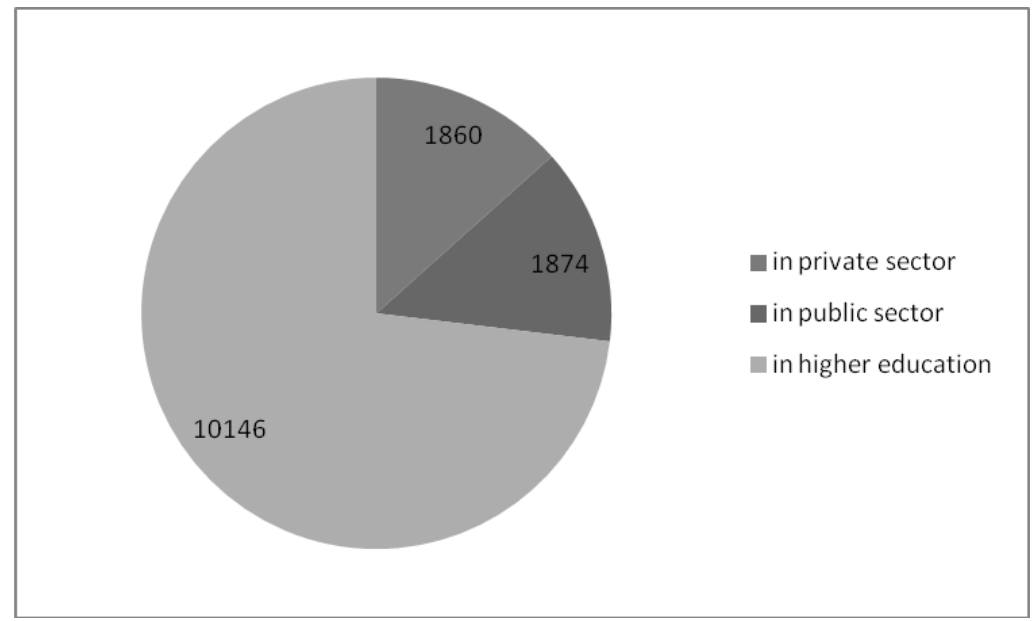

Chart 2. R\&D staff employed in different sectors in Małopolska (in 2009)

Source: Local Data Bank, Central Statistical Office

The biggest share of R\&D expenditure in the region in spent in engineering and technical science as well as natural science.

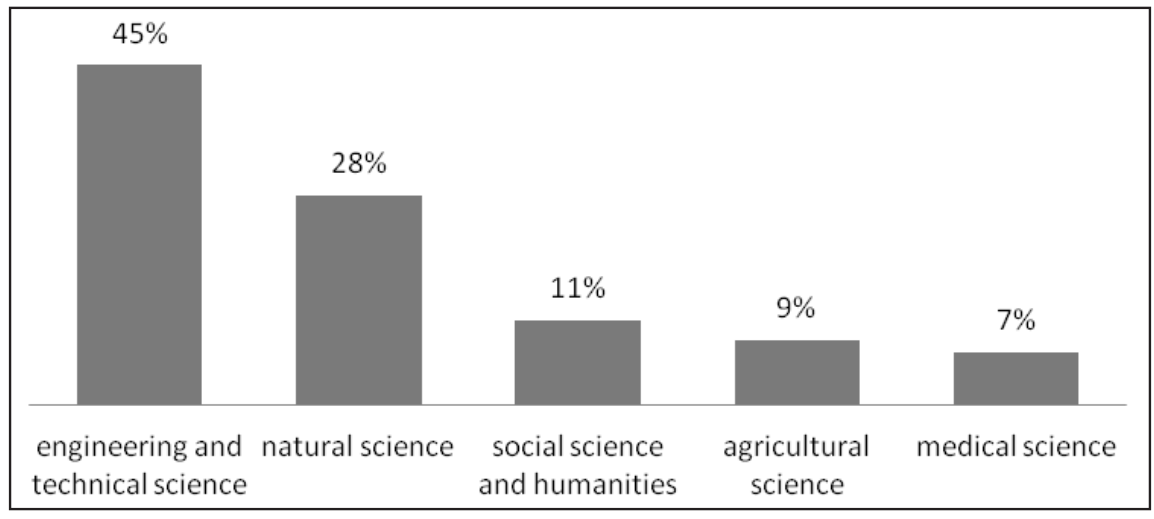

Chart 3. R\&D expenditure in sectors in Małopolska region (in 2009)

Source: Local Data Bank, Central Statistical Office

As it has already been mentioned, contexts rich in knowledge are characterized by a higher level of knowledge-intensive start-ups, which implies a significant role of universities and other research and educational institutions as factors influencing academic entrepreneurship. Thus, incubator organizations play a crucial role since they enable firms to locate in geographical proximity of universities, usually in the centre of a city, where the costs of living and housing are higher than outside the metropolitan area (Audretsch and Lehmann 
2005: 1194). When it comes to the institutional infrastructure, the Małopolska region has a quite developed system of institutions supporting academic entrepreneurship. There are five centres of knowledge transfer, all of them located in Kraków. Similarly, all nine business incubators are located in the capital of the region. Among four technological parks, two are in Kraków, one in Tarnów and one in Nowy Sącz. Concerning clusters of entrepreneurship, most of them are concentrated in Kraków. That disproportion in localization of infrastructure within the region is a serious obstacle to its sustainable development.

To sum up, Małopolska is a region with high potential for the development of academic entrepreneurship. The high number of universities is in line with the significant number of students, graduates and scientists. The higher education sector plays a significant role in the region when it comes to $\mathrm{R} \& \mathrm{D}$ expenditure and staffing.

\section{ACADEMIC ENTREPRENEURSHIP IN THE MAŁOPOLSKA REGION}

Taking into consideration the high potential of research and development in the region, it is striking that academic entrepreneurship is not yet well established in Małopolska.

Only three universities introduced the procedure of establishing spin-offs (the Jagiellonian University in 2007, the Kraków University of Technology and AGH University of Science and Technology in 2011). However, there are only five spin-offs existing: three at the Jagiellonian University (in the following sectors: biotechnology, microbiology, chemistry; source: http:/www.cittru.uj.edu.pl/?q=pl/node/428/) and two at AGH University of Science and Technology (in telemedicine and construction of rotor platforms). The latter were established within a special venture - INNOAGH Ltd. - the aim of which, as a seed capital fund, is to support the creation of spin-offs and to invest in their growth. Insufficient level of development of academic entrepreneurship within universities can be linked to the lack of procedures and rules on intellectual property rights and spin-offs, as well as to unfavourable climate and attitudes of the faculty towards scientists entering the business sector.

According to the results of a research study conducted in 2006 among the scientists employed in Kraków universities and research institutes, the most expected support from the parent institution in the creation of spin-offs is the provision of know-how, technological support and equipment, as well as guidance in marketing and promotion of a new venture. Financial and administrative support is mostly expected from external institutions (such as finance institutions, banks and government agencies) (Działek and Skalska 2006: 28).

Within the Operational Programme Human Capital, regional component VIII "Regional human resources for the economy", from 2007 to 2011, almost thirty projects financed by the European Social Fund, and aimed at promoting academic entrepreneurship were carried out by means of information campaigns and training offered to scientists, PhD students, students and graduates of the universities and research institutions in Małopolska. During this period, over one thousand persons took part in thorough training programmes in establishing and managing a spin-off/spin-out; the training included introduction to legal and financial aspects of entrepreneurial activity, marketing, management, as well as communication skills, negotiation tactics, and effective leadership. 
As for spin-outs, they are mainly funded within business incubators. A business incubator is an organization aimed at supporting the growth of start-ups by providing (free of charge or on preferential conditions) instruments of support and services, like physical space, capital, coaching, common services, and networking connections. All business incubators in the region have the following services in their offer: consulting in starting up a venture and running a business during the incubation period; administrative and legal support; access to physical space, common services and networking connections; secretary services; support in acquiring investment funding; support in networking; training; access to business press. Services are offered either free or on preferential conditions described in incubation agreements. This is crucial in the starting period of running a business and it enables business-beginners to concentrate on building the company's growth strategy. On the average, a company spends three up to five years in the incubator. In the last period of the incubation process, the charges for the services are similar to the market conditions. The aim of the incubation process is to promote effective and mature companies able to survive at the competitive market after the incubation phase.

There are nine business incubators in Małopolska, all of them situated in the capital of the region: Technological Incubator of the Kraków Technological Park; Bio-Incubator in Life-Science Park (running since 2011); Academic Business Incubator of AGH University of Science and Technology; Academic Business Incubator of the Kraków University of Technology; Academic Business Incubator of the Jagiellonian University; and four academic business incubators run by the Foundation for Academic Business Incubators in four Kraków universities: Kraków University of Economics, University of Agriculture in Kraków, Andrzej Frycz Modrzewski Kraków University, and Tischner European University. The greatest number of spin-outs were established within the network of the Foundation for Academic Business Incubators.

Tab. 5. Number of spin-outs in business incubators (2011)

\begin{tabular}{|l|c|}
\hline \multicolumn{1}{|c|}{ Name of the incubator } & $\begin{array}{c}\text { Number of spin-outs } \\
\text { in the incubator }\end{array}$ \\
\hline $\begin{array}{l}\text { Technological Incubator of the Kraków Technological } \\
\text { Park (IT KPT) }\end{array}$ & 26 \\
\hline $\begin{array}{l}\text { Academic Business Incubator of AGH University of } \\
\text { Science and Technology }\end{array}$ & 5 \\
\hline $\begin{array}{l}\text { Academic Business Incubator of Kraków University of } \\
\text { Technology }\end{array}$ & 1 \\
\hline Academic Business Incubator of Jagiellonian University & 7 \\
\hline $\begin{array}{l}\text { Academic Business Incubators run by the Foundation of } \\
\text { Academic Business Incubators on Kraków University } \\
\text { of Economics, University of Agriculture in Kraków, } \\
\text { Andrzej Frycz Modrzewski Kraków University and } \\
\text { Tischner European University }\end{array}$ & \\
\hline Overall number & 137 \\
\hline
\end{tabular}

Source: own analysis 
Start-ups functioning in business incubators are, in the majority, innovative ventures offering various IT services, including webmastering, mobile marketing, e-marketing, business intelligence, data mining, image-processing technology, or e-tourism. Four out of ten promising technologies selected by the experts within the framework of the project "Technology Perspective Kraków - Małopolska 2020" as those technology areas in which Małopolska should specialize are represented by spin-outs already existing in the region.

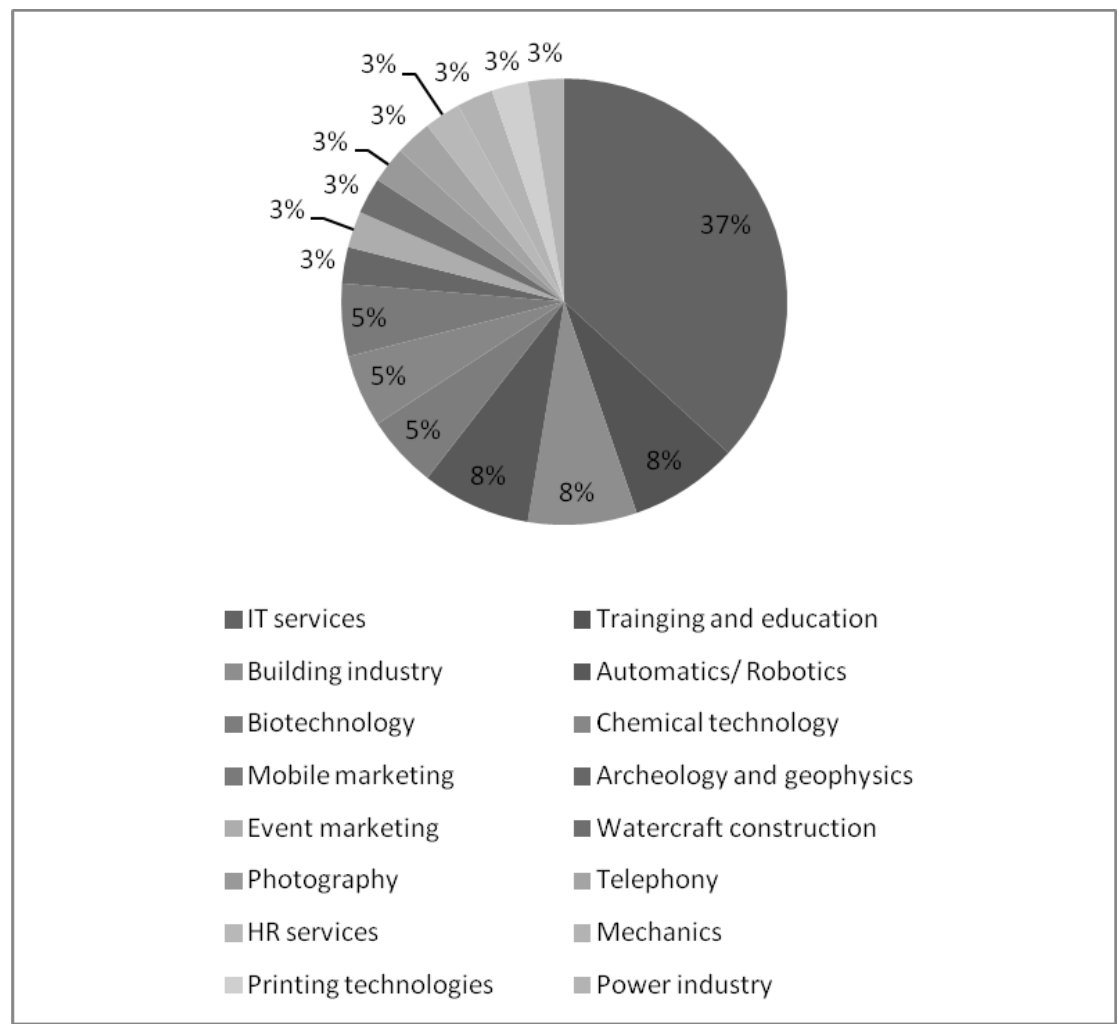

Chart 4. Business profile of spin-outs in Małopolska

Source: own analysis

Considering a significant academic potential of Małopolska, there is still a serious need to promote academic entrepreneurship in the region. One of the recommendations for the future regional development policy in the region, formulated within the framework of the project "Technology Perspective Kraków - Małopolska 2020", is to build a consistent programme of academic entrepreneurship support by means of education, promotion of entrepreneurial attitudes and intensification of support for spin-offs and spin-outs. 
Tab. 6. Most promising technologies in Małopolska

\begin{tabular}{|l|c|}
\hline \multicolumn{1}{|c|}{ Most promising technologies in Malopolska } & $\begin{array}{c}\text { Spin-outs } \\
\text { sectors }\end{array}$ \\
\hline Energy-saving building industry & \\
\hline Renewable energy technologies & $\sqrt{ }$ \\
\hline Materials engineering & $\sqrt{ }$ \\
\hline Tissue engineering & \\
\hline Anticancer medicines and technologies & \\
\hline Monitoring and control of diseases & \\
\hline Application of data analysis in medical treatment & \\
\hline No-touch computer interface & $\sqrt{ }$ \\
\hline Intelligent services & $\sqrt{ }$ \\
\hline Universal access to information & \\
\hline
\end{tabular}

Source: own analysis on the basis of Perspektywa technologiczna Kraków-Małopolska 2020, Wyzwania rozwojowe, Kraków-Warszawa 2011

\section{CONCLUSIONS}

The aim of the paper was to explain the foundations of the knowledge spillover theory of entrepreneurship and to illustrate this theoretical concept by referring to academic entrepreneurship in the Małopolska region.

As it has been shown, knowledge-based start-ups serve as a missing link between research activity and economic practice by enabling spillovers of knowledge that would otherwise remain uncommercialized. That mechanism can be observed also in the case of academic entrepreneurship. Spin-offs and spin-outs act as crucial channels of knowledge transfer by building business concepts on the basis of know-how acquired during academic education and former employment at the university. This type of activity can be a significant source of economic growth, also at the regional level.

In that context, it is crucial to further regional programmes aimed at promotion of academic entrepreneurship in Małopolska. The region in question presents an important academic potential and provides infrastructural and institutional framework within which to promote stable relations between the research and development sector and the business sector. Promotion of academic entrepreneurship should be one of the priorities of regional development strategies in the coming years. 


\section{References}

Alvarez S.A., Barney J.B., 2005, How do entrepreneurs organize under conditions of uncertainty?, "Journal of Management", 31, pp. 776-793.

Arrow K.J., 1962, Economic welfare and the allocation of resources for invention, [in:] R.R. Nelson (ed.), The Rate and Direction of Inventive Activity, Princeton, pp. 609-626.

Audretsch D.B, Keilbach M., 2005, The Knowledge Spillover Theory of Entrepreneurship, Indiana University and Max Planck Institute of Economics, November 2005.

Audretsch D.B, Keilbach M., 2007, The Theory of Knowledge Spillover Entrepreneurship, "Journal of Management Studies", 44 (7), pp. 1242-1254.

Audretsch D.B., Lehmann E.E., 2005, Does the knowledge spillover theory of entrepreneurship hold for the regions?, "Research Policy", 34, pp. 1191-1202.

Braunerhjelm P., Carlsson B., Acs Z., Audretsch D.B., 2010, The missing link: knowledge diffusion and entrepreneurship in endogenous growth, "Small Business Economics", vol. 34, issue 2, pp. 105-125.

Carlsson B., Acs Z., Audretsch D.B., Braunerhjelm P., 2009, Knowledge creation, entrepreneurship and economic growth: a historical review, "Industrial and Corporate Change", vol. 18, No 6, pp. 1193-1229.

Działek J., Skalska O., 2006, Raport z badania podaży innowacji w Małopolsce realizowanego w ramach projektu ,Wzmacnianie regionalnej strategii innowacji-RIS Małopolska”, Kraków 2006.

Franzoni C., Lissoni F., 2009, Academic entrepreneurs: critical issues and lessons for Europe, [in:] Universities, Knowledge Transfer and Regional Development, Cheltenham-Northmapton, pp. 163-190.

Koschatzky K., Hemer J., 2009, Firm formation and economic development: what drives academic spin-offs to success or failure?, [in:] Universities, Knowledge Transfer and Regional Development, Cheltenham-Northmapton, pp. 191-218.

Local Data Bank, Central Statistical Office, http://www.stat.gov.pl/bdl/app/strona.html?p_name=indeks Perspektywa technologiczna Kraków - Małopolska 2020, Wyzwania rozwojowe, Kraków-Warszawa 2011.

Ranking Uczelni Akadmickich 2012, http://www.perspektywy.pl/index.php?option=com_content\& task=view\&id=5074\&Itemid=909

\section{Academic entrepreneurship as a factor of knowledge spillovers in the regions - the case of Małopolska region}

With the transition towards a knowledge-based economy, entrepreneurship has become a focus of public policy, especially on the regional level, as one of the most significant factors of economic growth. The knowledge spillover theory of entrepreneurship is based on the assumption that entrepreneurs act as a missing link in the knowledge-based economy, by converting incompletely commercialized knowledge into economically significant one. They do so by founding new ventures - start-ups - in order to exploit knowledge created in larger companies, which are unwilling to commercialize new ideas due to a high level of uncertainty. In this sense, starting up a new company acts as a conduit for the spillover of knowledge. 
The aim of the paper is to explain the foundations of the knowledge spillover theory of entrepreneurship. In the second part of the paper, the analysis of the Małopolska region in the light of the knowledge spillover theory of entrepreneurship is carried out. The special focus is on academic entrepreneurship in the region, since the theoretical concept of knowledge spillover theory of entrepreneurship may well serve as a framework to analyze knowledge-based ventures.

Mgr Magdalena Godowska

Jagiellonian University

Institute of European Studies

e-mail: Magdalena.godowska@gmail.com 